\title{
Generation Mean Analysis for Yield and Its Contributing Traits in Rice (Oryza sativa L.)
}

\author{
C. S. Patel ${ }^{1}$, S.R. Patel $^{1}$, S.S. Patil ${ }^{1}$, Dinisha Abhishek ${ }^{1 *}$ and Arpan Nayak ${ }^{2}$ \\ ${ }^{1}$ Department of Genetics and Plant Breeding, Navsari Agricultural \\ University - Campus Bharuch, India \\ ${ }^{2}$ College of Agriculture, Parul University, Vadodara, India \\ *Corresponding author
}

\section{A B S T R A C T}

\section{Keywords}

Scaling test, gene action, Generation mean analysis, Rice (Oryza sativa L.)

Article Info

Accepted:

18 July 2020

Available Online:

10 August 2020

The present investigation was carried out during kharif 2017-2018, at Main Rice Research Centre farm, Navsari Agricultural University, Navsari. The experimental material for present investigation comprised of Six generations viz., $\mathrm{P}_{1}, \mathrm{P}_{2}, \mathrm{~F}_{1}, \mathrm{~F}_{2}, \mathrm{BC}_{1}$ and $\mathrm{BC}_{2}$ of following four crosses were involved eight diversified cultivars of rice (Oryza sativa $\mathrm{L}$.) were used to study the genetic analysis of quantitative and qualitative traits. The results of the scaling tests revealed that the additive-dominance model was inadequate for all of the characters evaluated in all of the four crosses, suggested the existence of epistasis in the inheritance of these characters. On the basis of six parameter model, main effect viz., mean $(\mathrm{m})$, additive (d) and dominance $(\mathrm{h})$ and all three digenic interactions viz., additive $\mathrm{x}$ additive (i), additive $x$ dominance (j) and dominance $x$ dominance (l) were significant for days to $50 \%$ flowering in cross 2 (GNR-3 X IET-25446) and cross 3 (GNR-5 X IET25471), for days to maturity in cross 2 (GNR-3 X IET-25446), for plant height in cross 2 (GNR-3 X IET-25446), for grain yield per plant in cross 4 (IET-15429 X IET-25453), for harvest index in cross 2 (GNR-3 X IET-25446), cross 3 (GNR-5 X IET-25471) and cross 4 (IET-15429 X IET-25453), for amylose content in cross 1 (NAUR-1 X IET-25457), for zinc content in cross 1 (NAUR-1 X IET-25457), for leaf area in cross 3 and for chlorophyll content in cross 3 (GNR-5 X IET-25471) indicated that involvement of additive, dominance as well as epistasis interaction for controlling this trait. The duplicate epistasis was observed in almost all traits except grains per panicle in cross 2 (GNR-3 X IET-25446), making it difficult to fix genotypes with increased level of character manifestation because the opposite effect of one parameter would be cancelled out by the negative effect of another parameter.

\section{Introduction}

Rice, being one of the most important cereal crops of India and Asia, is cultivated as pure culture mainly in Kharif. The crop is cultivated in large area but is characterized by very low productivity due to lack of high yielding varieties adapted to different seasons and agronomic conditions at different parts of country. As we know, yield is a complex end product of a number of components most of which are under polygenic control. So, all changes in yield must be accompanied by changes in one or more of the components as 
have been pointed out by Grafius (1959). The ultimate goal of any plant breeding programme is to develop improved genotypes which are better than their existing ones in one or more traits which producing the economic yield. The enhancement of mineral nutrients in rice is today's vital need to reduce malnutrition/anemic conditions in poor people of the world. Sufficient understanding of the inheritance of quantitative traits and information about heritability of grain yield, its components and quality traits are essential to develop an efficient breeding strategy.

Plant breeder is primarily concerned with improvement of traits directly or indirectly related to economic values. These traits are generally quantitative in nature and governed by number of genes each having small effect acting in cumulative manner such genes are called polygene (Mather, 1943). The knowledge of gene action helps in the selection of parents for use in hybridization programmes and also in the choice of appropriate breeding procedure for the genetic improvement of various characters.

Generation mean analysis is a useful technique in plant breeding for estimating main gene effects (additive and dominance) and their digenic (additive $\mathrm{x}$ additive, additive $\mathrm{x}$ dominance and dominance $\mathrm{x}$ dominance) interactions responsible for inheritance of quantitative traits. It helps us in understanding the performance of the parents used in crosses and potential of crosses to be used either for heterosis exploitation or pedigree selection. Considering the fact that grain yield and quality traits of rice are the most important complex traits and that their improvement is the most frequent goal of rice breeding programs in the world.

\section{Materials and Methods}

The material comprising of eight genetically diverse parents of rice (NAUR-1, IET-25457,
GNR-3, IET-25446, GNR-5, IET-25471, IET15429 and IET-25453) selected on the basis of their geographic origin and variation in morphological characters and based on their mineral nutrient content. four crosses (NAUR-1 X IET-25457, GNR-3 X IET25446, GNR-5 X IET-25471 and IET-15429 $X$ IET-25453) obtained by crossing of eight diverse parents during Kharif-2016 at Main Rice Research Centre farm, Navsari Agricultural University, Navsari. Back crossing was done in summer-2016-17 with its respective parents. Selfing of $F_{1}$ s was done in the same season (summer-2016-17) to get $\mathrm{F}_{2} \mathrm{~S}$. The evaluation trial was conducted in Kharif- 2017-18 at Main Rice Research Centre farm, Navsari Agricultural University, Navsari. The experimental material consisting of six generations $\left(\mathrm{P}_{1}, \mathrm{P}_{2}, \mathrm{~F}_{1}, \mathrm{~F}_{2}, \mathrm{BC}_{1}\right.$ and $\mathrm{BC}_{2}$ ) of each of the four crosses were sown during Kharif-2017-18 in compact family block design with three replications. Each replication was divided in four compact blocks. Each four crosses consisting of six generations were randomly allotted to each plot within a block. Each plot consisted of one row of parents and $F_{1} s$, two rows of the backcrosses and four rows of the $F_{2}$ generations of each cross. Inter and intra row spacing was $20 \mathrm{~cm}$ and $15 \mathrm{~cm}$ respectively. The experiment was surrounded by four guard rows to avoid damage and border effects.

\section{Results and Discussion}

In the present investigation, all the four scaling tests (A, B, C and D) were highly significant for all the characters under study, indicating inadequacy of additive-dominance model to explain the inheritance of yield and it's contributing traits characters. The values for individual scaling tests and estimates of mean (m), additive gene effect (d ), dominance gene effect (h) and epistatic interactions viz., additive $\mathrm{x}$ additive (i), additive $\mathrm{x}$ dominance $(\mathrm{j})$ and dominance $\mathrm{x}$ dominance (l) interactions are presented in 
tables 1 and 2 respectively. On the basis of individual scaling test $\mathrm{A}, \mathrm{B}, \mathrm{C}$ and $\mathrm{D}$ the additive-dominance model was found inadequate for description of variation in generation mean for all the traits of all the four crosses, either the entire four or any three, two or one individual scaling test (out of $\mathrm{A}, \mathrm{B} \mathrm{C}$ and $\mathrm{D}$ ) were found significant which indicated the presence of digenic interaction which implies that the additivedominance model is inadequate. This indicated that the genetic variation could not be described to additive and dominance effect alone but epistasis also plays a major role. When the simple additive-dominance model failed to explain the variation among the generation means, a six parameter model involving three digenic interaction parameters proposed by Hayman (1958) was applied.

The highly significant mean values from the generation mean analysis in all the crosses showed that the six generation differed from each other and these all studied traits are quantitatively inherited. The additive (d) effect found significant and positive in cross 1 for productive tillers per plant, grains per panicle, 100 seed weight, grain yield per plant, kernel L:B ratio; in case of cross 2 for plant height, productive tillers per plant, grains per panicle, 100 seed weight, grain yield per plant, harvest index, kernel L:B ratio; in case of cross 4 for days to maturity, plant height, grains per panicle, 100 seed weight, grain yield per plant, harvest index, kernel L:B ratio.

Similarly, the additive (d) effect found significant and negative for cross 1 in days to maturity; in case of cross 2 for days to $50 \%$ flowering, days to maturity; in case of cross 3 for days to $50 \%$ flowering, days to maturity, plant height, straw yield per plant.

The additive component of variation can be exploited by simple pedigree selection. Mass selection for several early generation aimed at the improvement of heterozygous population by modifying the frequencies of desirable genes followed by single plant selection in the resulting material would be cheapest and quickest procedure. However, the presence of non-fixable ( $h, j$ and 1$)$ component together with duplicate type of epistasis may cause delay in the improvement in this trait through selection in early generations. Under this situation, progeny could be achieved and the selection is delayed to later generations. These results are in agreement with those obtained by Nayak et al., (2007), Roy and Senapati (2011), Samak et al., (2011), Srivastav et al., (2012), Chamundeswari et al., (2013), Gnanamalar and Vivekanandan (2013), Kiani et al., (2013), Yadav et al., (2013), Mohamed et al., (2014), Montazeri et al., (2014), Shahid et al., (2014), Patel et al., (2015), Rani et al., (2015), Sultana et al., (2016) and Kumar et al., (2017) for days to $50 \%$ flowering, days to maturity, plant height, productive tillers per plant and harvest index.

The hybrid sowing positive and significant dominance (h) effects for plant height, 100 seed weight in cross 1 ; in case of cross 2 for days to $50 \%$ flowering, days to maturity; in case of cross 3 for days to $50 \%$ flowering, days to maturity, plant height. These results are in agreement with those obtained by Nayak et al., (2007) for grains per panicle, Roy and Senapati (2011), Samak et al., (2011), Srivastav et al., (2012) for 100 seed weight, Chamundeswari et al., (2013) for 100 seed weight, Gnanamalar and Vivekanandan (2013) for kernel L:B ratio, Kiani et al., (2013) for grains per panicle, 100 seed weight, Yadav et al., (2013), Mohamed et al., (2014) for 100 seed weight, straw yield per plant, chlorophyll content, Montazeri et al., (2014), Shahid et al., (2014), Patel (2015) for productive tillers per plant, grains per panicle, 100 seed weight, grain yield per plant, straw yield per plant, harvest index, kernel L:B 
ratio, Rani et al., (2015), Sultana et al., (2016) for grains per panicle, 100 seed weight, kernel L:B ratio and Kumar et al., (2017) for kernel $\mathrm{L}: \mathrm{B}$ ratio.

Significant and negative dominance (h) effect was observed for grains per panicle and harvest index in cross 1 ; in case of cross 2 plant height, grain yield per plant, harvest index; in case of cross 3 productive tillers per plant, 100 seed weight, harvest index; in case of cross 4 productive tillers per plant, grain yield per plant and harvest index, respectively.

The magnitude of dominance (h) component was higher than that of additive (d) effect, suggesting greater importance of dominance effect in the expression of all the studied characters. For the exploitation of dominance effect non-conventional breeding procedure might be adopted. Epistasis gene effects are known to contribute a sizable part of variation in the genetic makeup of character which shows higher estimate of dominance effects (Gamble, 1962). In the present investigation also, high estimate of dominance (h) effect for above traits were associated with significant epistasis interaction in the respective crosses.

Considering the contribution of epistasis gene effect for any character in relation to magnitude, dominance $\mathrm{x}$ dominance (l) interaction had enhancing effect as compare to additive $\mathrm{x}$ additive (i) and additive $\mathrm{x}$ dominance $(j)$ in the expression of days to 50 $\%$ flowering in cross 1 ; for days to maturity in cross 1; for plant height in cross 2; for productive tillers per plant in cross 2 , cross 3 and cross 4; for grains per panicle in all crosses; for 100 seed weight in all crosses except cross 1; for grain yield per plant in all crosses; for straw yield per plant in all crosses; for harvest index in all crosses; for kernel L:B ratio in all crosses. Non fixable gene effect were important in the expression of these traits in these crosses could be exploited by bi-parental mating of recurrent selection or the use of population improvement concept as an alternative to conventional method.

The sign of dominance $\mathrm{x}$ dominance (1) effect was negative for plant height, in cross 1; days to $50 \%$ flowering, days to maturity, straw yield per plant in cross 2; days to $50 \%$ flowering and days to maturity, straw yield per plant in cross 3 ; days to $50 \%$ flowering, straw yield per plant in cross 4 indicating their reducing effect in the expression of these characters, while negative sign of dominance $\mathrm{x}$ dominance (1) component for days to $50 \%$ flowering and days to maturity in cross 2 and cross 3; days to $50 \%$ flowering in cross 4 suggesting the beneficial effect for early flowering and maturity of this crop. The sign of dominance $\mathrm{x}$ dominance (l) component was positive in the other character indicating their enhancing effect in the expression of that character in all four crosses of rice.

The additive $\mathrm{x}$ additive (i) interaction had greater effect as compare to additive $\mathrm{x}$ dominance $(j)$ and dominance $x$ dominance (l) effect in the expression of days to $50 \%$ flowering in cross 2 , cross 3 and cross 4 ; for days to maturity in cross 2 , cross 3 and cross 4; for plant height in cross 1 and cross 3 ; for productive tillers per plant in cross 1 ; for 100 seed weight in cross 1 . This indicated better response to selection pressure in population for these characters. In these crosses, improvement could be made by cyclic method of breeding in which desirable recombinants are selected and intercrossed to pool the favorable genes for synthesizing the elite population.

Estimate of additive (d) and dominance (h) component varied from cross to cross and character to character. The variable expression of gene effect in different crosses 
might be due to the genetic makeup of a particular cross and the effect of environmental condition on the expression of different traits. As in the present study, the significance additive and additive $\mathrm{x}$ additive epistasis was observed in cross 2 and 3 for days to $50 \%$ flowering; in cross 2 , cross 3 and cross 4 for days to maturity; in cross 2 and 3 for plant height; in cross 2 for productive tillers per plant; in cross 1 for grains per panicle; in cross 1 for 100 seed weight; in cross 2 and cross 4 for grain yield per plant; in cross 2, 3 and cross 4 for harvest index.

Table.1 Scaling test for yield and its contributing characters aromatic in Rice (as per Mather, 1949)

\begin{tabular}{|c|c|c|c|c|c|c|c|c|c|c|c|c|}
\hline & \multicolumn{3}{|c|}{ I } & \multicolumn{3}{|c|}{ II } & \multicolumn{3}{|c|}{ III } & \multicolumn{3}{|c|}{ IV } \\
\hline \multicolumn{13}{|c|}{ Days to $50 \%$ flowering } \\
\hline A & $-3.40^{*}$ & \pm & 1.61 & -1.13 & \pm & 1.65 & -1.13 & \pm & 1.87 & $4.80 *$ & \pm & 2.13 \\
\hline B & $-9.07 * *$ & \pm & 2.41 & $4.67 * *$ & \pm & 1.45 & $6.27 * *$ & \pm & 1.74 & 0.20 & \pm & 2.06 \\
\hline C & -5.07 & \pm & 3.47 & $-6.00 *$ & \pm & 2.57 & $-7.87 *$ & \pm & 3.14 & -1.93 & \pm & 3.24 \\
\hline D & $3.70^{*}$ & \pm & 1.77 & $-4.77 * *$ & \pm & 1.17 & $-6.5 * *$ & \pm & 1.30 & $-3.47 *$ & \pm & 1.74 \\
\hline \multicolumn{13}{|c|}{ days to maturity } \\
\hline A & $-7.33 * *$ & \pm & 2.45 & -0.20 & \pm & 2.22 & 3.53 & \pm & 2.36 & $5.80 * *$ & \pm & 1.97 \\
\hline B & $-6.67 * *$ & \pm & 2.54 & $6.53 * *$ & \pm & 1.99 & $8.53 * *$ & \pm & 2.06 & -2.87 & \pm & 1.96 \\
\hline C & $-11.87 * *$ & \pm & 4.07 & $-9.00 * *$ & \pm & 3.25 & $-8.67 *$ & \pm & 3.83 & -3.53 & \pm & 3.00 \\
\hline D & 1.07 & \pm & 2.07 & $-7.67 * *$ & \pm & 1.67 & $-10.37 * *$ & \pm & 1.69 & $-3.23^{*}$ & \pm & 1.60 \\
\hline \multicolumn{13}{|c|}{ plant height $(\mathrm{cm})$} \\
\hline $\mathbf{A}$ & -8.00 & \pm & 5.67 & 5.13 & \pm & 5.92 & $-24.67 * *$ & \pm & 5.48 & $11.27^{*}$ & \pm & 5.33 \\
\hline B & -3.60 & \pm & 6.06 & -13.33 & \pm & 7.50 & 6.53 & \pm & 5.45 & $-11.73^{*}$ & \pm & 5.55 \\
\hline C & $-32.47 * *$ & \pm & 9.67 & $35.87 * *$ & \pm & 11.2 & $-43.00 * *$ & \pm & 9.88 & 3.67 & \pm & 9.15 \\
\hline D & $-10.43^{*}$ & \pm & 4.59 & $22.03 * *$ & \pm & 6.41 & $-12.43 * *$ & \pm & 3.97 & 2.07 & \pm & 4.03 \\
\hline \multicolumn{13}{|c|}{ Productive tillers per plant } \\
\hline $\mathbf{A}$ & $1.47^{*}$ & \pm & 0.67 & -0.87 & \pm & 0.73 & -0.07 & \pm & 0.68 & $-2.33 * *$ & \pm & 0.62 \\
\hline B & $-1.47 *$ & \pm & 0.62 & $-1.67 *$ & \pm & 0.76 & 1.00 & \pm & 0.81 & $-1.47 *$ & \pm & 0.69 \\
\hline C & -0.40 & \pm & 1.03 & 0.27 & \pm & 1.28 & $3.60 * *$ & \pm & 1.25 & 0.73 & \pm & 1.05 \\
\hline D & -0.20 & \pm & 0.49 & $1.40^{*}$ & \pm & 0.56 & $1.33^{*}$ & \pm & 0.57 & $2.27 * *$ & \pm & 0.49 \\
\hline \multicolumn{13}{|c|}{ grains per panicle } \\
\hline $\mathbf{A}$ & $-40.74 * *$ & \pm & 13.23 & $-17.93^{*}$ & \pm & 7.25 & $-29.35 * *$ & \pm & 5.88 & $-14.44 *$ & \pm & 6.19 \\
\hline B & $-41.29 * *$ & \pm & 12.25 & $-18.87 * *$ & \pm & 6.58 & -12.49 & \pm & 6.57 & $-29.71 * *$ & \pm & 5.96 \\
\hline C & -26.96 & \pm & 22.42 & $-35.35 * *$ & \pm & 12.80 & $-27.09^{*}$ & \pm & 10.79 & $-38.65 * *$ & \pm & 10.00 \\
\hline D & $27.54 * *$ & \pm & 10.26 & 0.73 & \pm & 4.93 & 7.37 & \pm & 4.97 & 2.75 & \pm & 4.36 \\
\hline
\end{tabular}

$*, * *$ Significant at $5 \%$ and $1 \%$ levels, respectively

I: NAUR-1 X IET-25457, II: GNR-3 X IET-25446,

III: GNR-5 X IET-25471, IV: IET-15429 X IET-25453 


\begin{tabular}{|c|c|c|c|c|c|c|c|c|c|c|c|c|}
\hline & \multicolumn{3}{|c|}{$\mathbf{I}$} & \multicolumn{3}{|c|}{ II } & \multicolumn{3}{|c|}{ III } & \multicolumn{3}{|c|}{ IV } \\
\hline \multicolumn{13}{|c|}{100 seed weight (g) } \\
\hline $\mathbf{A}$ & -0.08 & \pm & 0.10 & 0.04 & \pm & 0.08 & -0.13 & \pm & 0.09 & 0.04 & \pm & 0.08 \\
\hline B & -0.10 & \pm & 0.15 & $-0.58 * *$ & \pm & 0.14 & 0.03 & \pm & 0.09 & $-0.58 * *$ & \pm & 0.14 \\
\hline $\mathbf{C}$ & $-1.01 * *$ & \pm & 0.19 & $-0.47 * *$ & \pm & 0.18 & $0.86 * *$ & \pm & 0.13 & $-0.47 * *$ & \pm & 0.18 \\
\hline D & $-0.42 * *$ & \pm & 0.10 & 0.04 & \pm & 0.09 & $0.48 * *$ & \pm & 0.08 & 0.04 & \pm & 0.09 \\
\hline \multicolumn{13}{|c|}{ Grain yield per plant (g) } \\
\hline $\mathbf{A}$ & $-5.23 *$ & \pm & 2.34 & $-4.39 *$ & \pm & 1.96 & $-4.51 *$ & \pm & 2.26 & 0.30 & \pm & 2.52 \\
\hline B & $-5.34 *$ & \pm & 2.07 & $-6.28 * *$ & \pm & 1.65 & -0.89 & \pm & 2.62 & $-5.09 * *$ & \pm & 1.91 \\
\hline C & -5.45 & \pm & 3.77 & -1.72 & \pm & 3.34 & 4.99 & \pm & 4.48 & $9.19 *$ & \pm & 3.72 \\
\hline D & 2.56 & \pm & 1.69 & $4.48^{*}$ & \pm & 1.89 & $5.20 *$ & \pm & 2.15 & $6.99 * *$ & \pm & 1.69 \\
\hline \multicolumn{13}{|c|}{ Straw yield per plant (g) } \\
\hline $\mathbf{A}$ & $-5.87 *$ & \pm & 2.36 & 1.68 & \pm & 3.39 & 3.22 & \pm & 3.65 & $7.61 *$ & \pm & 3.06 \\
\hline B & -4.01 & \pm & 2.13 & $10.38 * *$ & \pm & 2.82 & $15.33^{* *}$ & \pm & 3.64 & $9.53 * *$ & \pm & 2.79 \\
\hline $\mathbf{C}$ & -2.68 & \pm & 3.87 & 2.08 & \pm & 4.81 & 8.79 & \pm & 6.35 & $10.94 *$ & \pm & 4.92 \\
\hline D & $3.60 *$ & \pm & 1.81 & -4.99 & \pm & 2.75 & -4.88 & \pm & 3.00 & -3.10 & \pm & 2.36 \\
\hline \multicolumn{13}{|c|}{ Harvest index (\%) } \\
\hline $\mathbf{A}$ & $-3.56 * *$ & \pm & 0.90 & $-8.41^{* *}$ & \pm & 2.54 & $-8.64 * *$ & \pm & 2.43 & $-7.62 * *$ & \pm & 2.55 \\
\hline B & $-2.73 * *$ & \pm & 0.56 & $-18.96 * *$ & \pm & 2.16 & $-15.54 * *$ & \pm & 2.04 & $-15.74 * *$ & \pm & 1.99 \\
\hline $\mathbf{C}$ & $-3.55^{* *}$ & \pm & 1.15 & -2.88 & \pm & 3.94 & -2.07 & \pm & 3.67 & -0.04 & \pm & 3.45 \\
\hline D & $1.37 *$ & \pm & 0.59 & $12.24 * *$ & \pm & 1.89 & $11.05^{* *}$ & \pm & 1.73 & $11.66^{* *}$ & \pm & 1.65 \\
\hline \multicolumn{13}{|c|}{ Kernel L:B ratio } \\
\hline $\mathbf{A}$ & 0.01 & \pm & 0.13 & -0.05 & \pm & 0.11 & 0.01 & \pm & 0.11 & -0.06 & \pm & 0.10 \\
\hline B & $-0.87 * *$ & \pm & 0.16 & $-0.68 * *$ & \pm & 0.15 & $-0.68 * *$ & \pm & 0.17 & $-0.61 * *$ & \pm & 0.15 \\
\hline C & $-0.56^{*}$ & \pm & 0.23 & $-0.70 * *$ & \pm & 0.21 & $-0.46^{*}$ & \pm & 0.23 & $-0.80^{* *}$ & \pm & 0.21 \\
\hline D & 0.15 & \pm & 0.11 & 0.01 & \pm & 0.11 & 0.11 & \pm & 0.10 & -0.07 & \pm & 0.11 \\
\hline
\end{tabular}

$*$, ** Significant at $5 \%$ and $1 \%$ levels, respectively I: NAUR-1 X IET-25457, II: GNR-3 X IET-25446,

III: GNR-5 X IET-25471, IV: IET-15429 X IET-25453 
Table.2 Estimation of gene effect of yield and quality traits through generation mean analysis

\begin{tabular}{|c|c|c|c|c|c|c|c|c|c|c|c|c|}
\hline & \multicolumn{3}{|c|}{$\mathbf{I}$} & \multicolumn{3}{|c|}{ II } & \multicolumn{3}{|c|}{ III } & \multicolumn{3}{|c|}{ IV } \\
\hline \multicolumn{13}{|c|}{ Days to $50 \%$ flowering } \\
\hline $\mathbf{m}$ & $91.72 * *$ & \pm & 0.67 & $90.28 * *$ & \pm & 0.46 & $90.45 * *$ & \pm & 0.52 & $90.58 * *$ & \pm & 0.62 \\
\hline d & -1.40 & \pm & 1.16 & $-4.27 * *$ & \pm & 0.73 & $-4.27 * *$ & \pm & 0.78 & 2.17 & \pm & 1.22 \\
\hline $\mathbf{h}$ & -5.63 & \pm & 3.71 & $10.63^{* *}$ & \pm & 2.51 & $12.03^{* *}$ & \pm & 2.85 & 5.2 & \pm & 3.63 \\
\hline $\mathbf{i}$ & $-7.40 *$ & \pm & 3.54 & $9.53 * *$ & \pm & 2.34 & $13.00 * *$ & \pm & 2.60 & $6.93 *$ & \pm & 3.47 \\
\hline $\mathbf{j}$ & $2.83^{*}$ & \pm & 1.27 & $-2.9 * *$ & \pm & 1.04 & $-3.7^{* *}$ & \pm & 1.13 & 2.3 & \pm & 1.34 \\
\hline 1 & $19.87 * *$ & \pm & 5.80 & $-13.07 * *$ & \pm & 3.88 & $-18.13 * *$ & \pm & 4.42 & $-11.93 *$ & \pm & 5.85 \\
\hline \multicolumn{13}{|c|}{ Days to maturity } \\
\hline m & $118.32 * *$ & \pm & 0.76 & $117.23 * *$ & \pm & 0.60 & $117.70 * *$ & \pm & 0.67 & $119.20^{* *}$ & \pm & 0.58 \\
\hline d & $-4.23^{* *}$ & \pm & 1.40 & $-3.73^{* *}$ & \pm & 1.16 & $-2.70 * *$ & \pm & 1.04 & $4.23 * *$ & \pm & 1.10 \\
\hline h & -0.70 & \pm & 4.35 & $16.23 * *$ & \pm & 3.52 & $20.87 * *$ & \pm & 3.65 & 5.23 & \pm & 3.33 \\
\hline $\mathbf{i}$ & -2.13 & \pm & 4.14 & $15.33 * *$ & \pm & 3.34 & $20.73 * *$ & \pm & 3.38 & $6.47 *$ & \pm & 3.19 \\
\hline $\mathbf{j}$ & -0.33 & \pm & 1.56 & $-3.37 *$ & \pm & 1.39 & -2.50 & \pm & 1.39 & $4.33 * *$ & \pm & 1.32 \\
\hline 1 & $16.13^{*}$ & \pm & 6.93 & $-21.67 * *$ & \pm & 5.66 & $-32.80 * *$ & \pm & 5.65 & -9.40 & \pm & 5.33 \\
\hline \multicolumn{13}{|c|}{ Plant height $(\mathrm{cm})$} \\
\hline $\mathbf{m}$ & $107.78 * *$ & \pm & 1.65 & $116.72 * *$ & \pm & 2.46 & $101.53 * *$ & \pm & 1.55 & $114.83 * *$ & \pm & 1.49 \\
\hline d & 3.00 & \pm & 3.20 & $11.93 * *$ & \pm & 4.11 & $-10.83 * *$ & \pm & 2.48 & $8.73 * *$ & \pm & 2.70 \\
\hline h & $26.67 * *$ & \pm & 9.84 & $-31.03^{*}$ & \pm & 13.11 & $27.63 * *$ & \pm & 8.83 & 3.50 & \pm & 8.77 \\
\hline $\mathbf{i}$ & $20.87^{*}$ & \pm & 9.19 & $-44.07 * *$ & \pm & 12.83 & $24.87 * *$ & \pm & 7.95 & -4.13 & \pm & 8.05 \\
\hline $\mathbf{j}$ & -2.20 & \pm & 3.43 & $9.23 *$ & \pm & 4.61 & $-15.60 * *$ & \pm & 2.99 & $11.5^{* *}$ & \pm & 3.21 \\
\hline 1 & -9.27 & \pm & 16.03 & $52.27 * *$ & \pm & 19.94 & -6.73 & \pm & 14.01 & 4.60 & \pm & 14.16 \\
\hline \multicolumn{13}{|c|}{ Productive tillers per plant } \\
\hline m & $8.05 * *$ & \pm & 0.17 & $8.13 * *$ & \pm & 0.21 & $8.43 * *$ & \pm & 0.21 & $7.68 * *$ & \pm & 0.18 \\
\hline d & $1.77 * *$ & \pm & 0.34 & $0.87 *$ & \pm & 0.37 & -0.40 & \pm & 0.37 & -0.03 & \pm & 0.34 \\
\hline $\mathbf{h}$ & 0.63 & \pm & 1.04 & -2.13 & \pm & 1.22 & $-2.80^{*}$ & \pm & 1.22 & $-4.07 * *$ & \pm & 1.06 \\
\hline $\mathbf{i}$ & 0.40 & \pm & 0.97 & $-2.80^{*}$ & \pm & 1.11 & $-2.67 *$ & \pm & 1.13 & $-4.53 * *$ & \pm & 0.99 \\
\hline $\mathbf{j}$ & $1.47 * *$ & \pm & 0.39 & 0.40 & \pm & 0.43 & -0.53 & \pm & 0.46 & -0.43 & \pm & 0.40 \\
\hline 1 & -0.40 & \pm & 1.71 & $5.33 * *$ & \pm & 1.96 & 1.73 & \pm & 1.95 & $8.33 * *$ & \pm & 1.73 \\
\hline \multicolumn{13}{|c|}{ Grains per panicle } \\
\hline m & $124.57 * *$ & \pm & 3.93 & $125.69^{* *}$ & \pm & 1.95 & $132.24 * *$ & \pm & 1.87 & $131.65^{* *}$ & \pm & 1.62 \\
\hline d & $12.95^{*}$ & \pm & 6.61 & $11.43^{* *}$ & \pm & 3.03 & 0.58 & \pm & 3.27 & $11.35^{* *}$ & \pm & 2.92 \\
\hline h & $-45.56^{*}$ & \pm & 22.03 & -3.86 & \pm & 11.10 & -3.37 & \pm & 10.68 & -0.01 & \pm & 9.52 \\
\hline $\mathbf{i}$ & $-55.07 * *$ & \pm & 20.53 & -1.45 & \pm & 9.86 & -14.75 & \pm & 9.94 & -5.49 & \pm & 8.72 \\
\hline $\mathbf{j}$ & 0.28 & \pm & 7.42 & 0.47 & \pm & 3.60 & $-8.43 *$ & \pm & 3.62 & $7.63^{*}$ & \pm & 3.72 \\
\hline 1 & $137.11 * *$ & \pm & 34.65 & $38.26^{*}$ & \pm & 17.63 & $56.59 * *$ & \pm & 16.96 & $49.64 * *$ & \pm & 15.37 \\
\hline
\end{tabular}




\begin{tabular}{|c|c|c|c|c|c|c|c|c|c|c|c|c|}
\hline & \multicolumn{3}{|c|}{ I } & \multicolumn{3}{|c|}{ II } & \multicolumn{3}{|c|}{ III } & \multicolumn{3}{|c|}{ IV } \\
\hline \multicolumn{13}{|c|}{100 seed weight (g) } \\
\hline $\mathbf{m}$ & $2.14 * *$ & \pm & 0.04 & $2.47 * *$ & \pm & 0.04 & $2.5^{* *}$ & \pm & 0.03 & $2.07 * *$ & \pm & 0.04 \\
\hline d & $0.14^{*}$ & \pm & 0.07 & $0.42 * *$ & \pm & 0.06 & -0.06 & \pm & 0.05 & $0.42 * *$ & \pm & 0.06 \\
\hline h & $0.86^{* *}$ & \pm & 0.21 & -0.16 & \pm & 0.19 & $-0.85 * *$ & \pm & 0.16 & -0.16 & \pm & 0.19 \\
\hline i & $0.84 * *$ & \pm & 0.20 & -0.07 & \pm & 0.18 & $-0.96^{* *}$ & \pm & 0.15 & -0.07 & \pm & 0.18 \\
\hline $\mathbf{j}$ & 0.01 & \pm & 0.08 & $0.31 * *$ & \pm & 0.08 & -0.08 & \pm & 0.06 & $0.31 * *$ & \pm & 0.08 \\
\hline 1 & -0.66 & \pm & 0.34 & $0.61^{*}$ & \pm & 0.30 & $1.07 * *$ & \pm & 0.25 & $0.61 *$ & \pm & 0.30 \\
\hline \multicolumn{13}{|c|}{ Grain yield per plant (g) } \\
\hline $\mathbf{m}$ & $21.23 * *$ & \pm & 0.65 & $21.35 * *$ & \pm & 0.75 & $24.4^{* * *}$ & \pm & 0.86 & $23.73^{* *}$ & \pm & 0.63 \\
\hline d & $2.20 *$ & \pm & 1.07 & $4.59 * *$ & \pm & 1.14 & 0.20 & \pm & 1.27 & $2.93 * *$ & \pm & 1.13 \\
\hline h & -4.29 & \pm & 3.64 & $-7.98 *$ & \pm & 3.85 & -7.24 & \pm & 4.52 & $-12.99 * *$ & \pm & 3.65 \\
\hline $\mathbf{i}$ & -5.12 & \pm & 3.37 & $-8.96^{*}$ & \pm & 3.78 & $-10.39 *$ & \pm & 4.29 & $-13.98 * *$ & \pm & 3.39 \\
\hline $\mathbf{j}$ & 0.05 & \pm & 1.36 & 0.94 & \pm & 1.21 & -1.81 & \pm & 1.53 & $2.70 *$ & \pm & 1.35 \\
\hline l & $15.68 * *$ & \pm & 5.71 & $19.63 * *$ & \pm & 5.65 & $15.8 *$ & \pm & 6.78 & $18.77 * *$ & \pm & 5.86 \\
\hline \multicolumn{13}{|c|}{ Straw yield per plant (g) } \\
\hline $\mathbf{m}$ & $25.57 * *$ & \pm & 0.70 & $23.23^{* *}$ & \pm & 1.00 & $26.29 * *$ & \pm & 1.18 & $25.63^{* * *}$ & \pm & 0.90 \\
\hline d & 0.83 & \pm & 1.14 & -2.18 & \pm & 1.88 & $-5.54 * *$ & \pm & 1.85 & -2.21 & \pm & 1.53 \\
\hline h & -5.36 & \pm & 3.86 & 9.09 & \pm & 5.65 & 11.05 & \pm & 6.37 & 6.35 & \pm & 5.01 \\
\hline $\mathbf{i}$ & $-7.19 *$ & \pm & 3.62 & 9.98 & \pm & 5.49 & 9.77 & \pm & 6.00 & 6.20 & \pm & 4.71 \\
\hline $\mathbf{j}$ & -0.93 & \pm & 1.39 & $-4.35^{*}$ & \pm & 2.09 & $-6.06 * *$ & \pm & 2.31 & -0.96 & \pm & 1.84 \\
\hline $\mathbf{l}$ & $17.07 * *$ & \pm & 6.00 & $-22.04 *$ & \pm & 8.94 & $-28.32 * *$ & \pm & 9.76 & $-23.33 * *$ & \pm & 7.86 \\
\hline \multicolumn{13}{|c|}{ Harvest index (\%) } \\
\hline $\mathbf{m}$ & $45.25 * *$ & \pm & 0.21 & $48.41 * *$ & \pm & 0.73 & $48.94 * *$ & \pm & 0.66 & $48.58^{* *}$ & \pm & 0.60 \\
\hline d & 0.12 & \pm & 0.41 & $7.26^{* *}$ & \pm & 1.20 & $5.32 * *$ & \pm & 1.11 & $5.60^{* * *}$ & \pm & 1.14 \\
\hline $\mathrm{h}$ & $-3.46^{* *}$ & \pm & 1.25 & $-22.3^{* *}$ & \pm & 4.01 & $-20.32 * *$ & \pm & 3.68 & $-22.56 * *$ & \pm & 3.52 \\
\hline i & $-2.74 *$ & \pm & 1.19 & $-24.49 * *$ & \pm & 3.79 & $-22.11 * *$ & \pm & 3.46 & $-23.31 * *$ & \pm & 3.29 \\
\hline $\mathbf{j}$ & -0.41 & \pm & 0.49 & $5.27 * *$ & \pm & 1.54 & $3.45^{*}$ & \pm & 1.48 & $4.06 * *$ & \pm & 1.54 \\
\hline 1 & $9.03 * *$ & \pm & 2.00 & $51.85 * *$ & \pm & 6.21 & $46.29 * *$ & \pm & 5.76 & $46.67 * *$ & \pm & 5.70 \\
\hline \multicolumn{13}{|c|}{ Kernel L:B ratio } \\
\hline m & $2.74 * *$ & \pm & 0.04 & $2.53^{* *}$ & \pm & 0.04 & $2.97 * *$ & \pm & 0.04 & $2.29 * *$ & \pm & 0.04 \\
\hline d & $0.52 * *$ & \pm & 0.08 & $0.41 * *$ & \pm & 0.07 & $0.29 * *$ & \pm & 0.07 & $0.37 * *$ & \pm & 0.07 \\
\hline h & -0.42 & \pm & 0.24 & -0.06 & \pm & 0.23 & -0.09 & \pm & 0.22 & 0.16 & \pm & 0.22 \\
\hline i & -0.30 & \pm & 0.23 & -0.03 & \pm & 0.22 & -0.22 & \pm & 0.20 & 0.13 & \pm & 0.21 \\
\hline $\mathbf{j}$ & $0.44 * *$ & \pm & 0.10 & $0.32^{* * *}$ & \pm & 0.09 & $0.35^{* *}$ & \pm & 0.08 & $0.28 * *$ & \pm & 0.09 \\
\hline 1 & $1.15^{* *}$ & \pm & 0.38 & $0.76^{*}$ & \pm & 0.36 & $0.89 *$ & \pm & 0.36 & 0.54 & \pm & 0.34 \\
\hline
\end{tabular}

*, ** Significant at $5 \%$ and $1 \%$ levels, respectively

I: NAUR-1 X IET-25457, II: GNR-3 X IET-25446,

III: GNR-5 X IET-25471, IV: IET-15429 X IET-2

These results are in agreement with those obtained by Nayak et al., (2007), Roy and Senapati (2011), Samak et al., (2011), Srivastav et al., (2012) for 100 seed weight, Chamundeswari et al., (2013) for 100 seed weight, Gnanamalar and Vivekanandan (2013) for kernel L:B ratio, Kiani et al., (2013) for grains per panicle,100 seed weight,
Yadav et al., (2013), Mohamed et al., (2014) for 100 seed weight, straw yield per plant, Montazeri et al., (2014), Shahid et al., (2014), Patel (2015) for productive tillers per plant, grains per panicle, 100 seed weight, grain yield per plant, straw yield per plant, harvest index, kernel L:B ratio, Rani et al., (2015), Sultana et al., (2016) for grains per panicle, 
100 seed weight, kernel L:B ratio and Kumar et al., (2017) for kernel L:B ratio.

In conclusion, the characters which controlled by additive gene effect can be improved by most appropriate method of breeding would be pedigree method of selection. In contrast to it other characters were controlled by additive and non-additive gene effects or non-additive gene effects in different crosses, hence those could be successfully improved by heterosis breeding or hybridization followed by cyclic method of breeding keeping adequate population size would be more desirable for improvement of these traits.

\section{References}

Suthar, S., 2007. Vermicomposting potential of Perionyx sansibaricus (Perrier) in different waste materials. Bioresour. Technol. 98, 1231-1237.

Gamble, E. E. 1962. Gene effects in corn (Zea mays L.) I. Separation and relative importance of gene effects for yield. Can. J. Pl. Sci., 42: 339-48.

Gnanamalar, R. P. and Vivekanandan, P. 2013. Genetic architecture of grain quality characters in rice (Oryza sativa L.). European J. of Exp. Bio, 3(2): 275279.

Grafius, J. E. 1959. Heterosis in barley. Agron. J., 51: 551-554.

Hanson, C. H., Robinson, H. F. C. and Comstock, R. E. 1956. Biometrical studies of yield in segregating populations of Korean Lespedeza. Agron, J., 48: 268-272.

Hayman, B. I. 1958. The separation of epistasis from additive and dominance variation in generation means. Heredity, 12: 371-390.

Hayman, B. I. 1960. Maximum likelihood estimation of genetic components of variation, Biometrics., 16: 369-381.

Kiani, S. H., Kazemitabar, S. K., Babaeian
Jelodar, N. A. and Ranjbar, G. A. 2013. Genetic evaluation of quantitative traits of rice (Oryza sativa L.) using generation mean analysis. Int. J. Agric. Crop Sci., 5(19): 2329-2336.

Kumar, A. and Senapati, B. K. 2013. Genetic parameters and association studies for important quantitative traits in advanced lines of Sambamahsuri derivatives. $J$. Crop \& Weed, 9(1): 156-163.

Mather, K. 1943. Polygenic inheritance and natural selection. Biol. Rev., 18: 32-64.

Mohamed, N. E. M. 2014. Genetic controls for some trats using generation mean analysis in bread wheat. Internationl journal of plant and soil science, 3(9): 1055-1068.

Montazeri, Z., Jelodar, N. B. and Bagheri, B. 2014. Genetic dissection of some important agronomic traits in rice using line $\mathrm{x}$ tester method. Int. J. Advanced Biol. Sci. and Biomed. Res., 2(1): 181191.

Panse, V. G. and Sukhatme, P. V. 1985. Statistical methods for agricultural workers. Indian Council of Agricultural Research, New Delhi.

Patel, S. K. 2015. Genetic analysis of yield and its components traits in rice (Oryza sativa L.). Electronic Journal of Plant Breeding, 6(1): 19-25.

Rani, P. J., Satyanarayana, P. V., Chamundeswari, N., Ahamed, M. L. and Rani, M. G. 2015. Studies on genetic control of quality traits in rice (Oryza sativa L.) using six parameter model of generation mean analysis. Electronic Journal of Plant Breeding, 6(3): 658-662.

Roy, S. K. and Senapati, B. K. 2011. Estimation of genetic components for grain yield and quality traits of rice. Oryza, 48(1): 22-30.

Samak, N., Hittalmani, S. and Biradar, H. 2011. Exploratory studies on genetic variability and genetic control for 
protein and micronutrient content in $\mathrm{F}_{4}$ and $\mathrm{F}_{5}$ generation of rice. Asian $\mathrm{J} . \mathrm{Pl}$. Sci. 10(7): 376-379.

Shahid, M. Q., Liu, G., Li, J., Naeem, M. and Liu, X. D. 2014. Heterosis and gene action study of agronomic traits in diploid and autotetraploid rice. Acta Agril. Scandinavica Section B-Soil and Pl. Sci., 61: 23-32.

Sharifi, P., Dehghani, H., Mo'ameni, A. and Moghaddam, M. 2011. Genetic assessments of some morphological traits in rice by generation mean analysis. Iranian Journal of Field Crop Science, 42(1): 1-13.

Singh, R. K. and Chaudhary B. D. 2004. Biometrical methods in quantitative genetics analysis. Kalyani publishers, Ludhiana.

Singh, R. K. and Chaudhary B. D. 2004.
Biometrical methods in quantitative genetics analysis. Kalyani publishers, Ludhiana.

Srivastava, A. K., Jaiswal, H. K., Agrawal, R. K. and Singh, R. P. 2012. Genetic architecture of yield and yield components in indigenous aromatic rice (Oryza sativa L.). Vegetos, 25(1): 146150.

Sultana, R., Ansari, N. A., Ramesha, M. S., Shankar, A. S. and Murali Krishna, K. 2016. Generation mean analysis of quantitative traits in restorer lines of rice (Oryza sativa L.). Asian journal of bio science, 11(1): 151-161.

Yadav, H. N., Prasad, R., Singh, S. P., Singh, R. P. and Agrawal, R. K. 2013. Detection of epistasis and gene effects for quality and yield traits in rice. Oryza, 2: 115-119.

\section{How to cite this article:}

Patel, C. S., S.R. Patel, S.S. Patil, Dinisha Abhishek and Arpan Nayak. 2020. Generation Mean Analysis for Yield and Its Contributing Traits in Rice (Oryza sativa L.). Int.J.Curr.Microbiol.App.Sci. 9(08): 1601-1610. doi: https://doi.org/10.20546/ijcmas.2020.908.184 